ARTICLE

Received 28 Sep 2015 | Accepted 17 Nov 2015 | Published 15 Dec $2015 \quad$ DOl: 10.1057/palcomms.2015.43

\title{
The passing of the peace: the ascension and the death of God
}

\author{
Christopher Rodkey ${ }^{1}$
}

\begin{abstract}
Is peace possible within a radical Christian perspective? This essay seeks to explore a radicalized notion of peace, an investigation that will also radicalize the doctrine of the ascension of Christ. To do so I begin with Paul Tillich, as a proto-radical theologian, and his understanding of peace, and point to its inadequacies, that is, namely, that Tillich assumes a universalized peace in an epoch yet to come, a peace that is hoped for without an actual faith in this peace. Second, drawing upon the radical theology of Thomas J J Altizer, a radical Christology that places exigency upon the presence of Jesus after the resurrection, as the Pauline "first fruits" or understanding or "Post-Christ", will emerge. A radical understanding of the ascension will usher a new understanding of peace for the church in a Pentecost age. This article is published as part of a collection dedicated to radical theologies.
\end{abstract}

\footnotetext{
${ }^{1}$ St. Paul's United Church of Christ, Dallastown, USA
} 
It is the passover of the Lord. For I will pass through the land Egypt that night ... on all the gods of Egypt I will execute judgements: I am the Lord.... This day shall be a day of remembrance for you. (Exodus 12:11b-12, 14a NRSV)

\section{T}

hroughout this investigation I rely upon resources within the radical theology tradition-for example, Mary Daly, DG Leahy, Peter Rollins, Slavoj Žižek-and employ their terminology and ideas both directly and indirectly. As someone who believes that theology is only radical when put into practice, and as my primary site of practice is the church, I intend my tone to be homiletic and to engage a practitioner within the context of liturgical expression. As such, I begin with a discussion of Tillich, who similarly understood his work as "on the boundary" between church and academy, and that the doing of theology occurs within the nexus of the two.

Tillich (1990) preached that Christians have a right to peace, as a right to believe in an "ultimate hope", even as we simultaneously experience the demonic with the holy all around us. This hope is neither entirely wrapped up in a religious belief in an afterlife, where God finally grants us peace, nor is it a hope beyond a human conception of time. Rather, this peace is a "hope for return to the eternal from which it comes"; this peace is not a heaven beyond space and time, but a return to being-itself: not distant or even in another dimension, but deeply and ontologically present in the immediate reality of the Now. Such hope, says Tillich, gives us "assurance" and a "deeper and more real" participation into what concerns us ultimately. Finally, as this hope gives us peace we should be mindful, Tillich proclaimed, that the hope for life within the eternal is not peace unless it is understood as a universal gift to humanity. Otherwise hope is "poor and foolish", and is not genuinely peace (Tillich, 1990, p. 190). Our lives have a purpose of building the Kingdom of God in the present and immediate world, and not for the security of a real estate market beyond our dimension of reality.

Tillich (1990, p. 180) elsewhere wrote, in a response to Pope John XXIII's encyclical, Pacem in Terris, that world peace may be attained through the development of technology, even as this technology appeals to our existentially demonic nature. Here Tillich reveals his Idealist roots, yet he remains a twentiethcentury humanist and existentialist, writing that "there is no hope for a final stage of history in which peace and justice rule ... we cannot hope for a final stage of justice and peace within human history; but we can hope for partial victories over the forces of evil in a particular moment in time" (p. 181). Tillich here implies that in the future there will be a "final stage of history", a utopia initiated when God finally overcomes human evil and intervenes in the establishment of a new era of peace. And here lies a tension in much liberal Christian theology, that the hope for peace and justice must happen now because God does not intervene in the Now beyond our hands and faces, but yet there is also always for the liberal a hope and expectation of this final intervention of the divine working from outside of history.

A radical Christian approach to Tillich must grapple with the nondiachronal nature of Tillich's conception of God, and Tillich's theology of peace is rooted in a belief in a metaphysical God that primarily stands above and beside history, rather than participating in history. Tillich may believe that God transforms the world, but when human acts work for justice these acts are not really the full work of deity in the world, but a small gesture of that God. To be sure, this is Mary Daly's critique of Tillich, namely, that Tillich points towards the possibility of a radicalized notion of divinity but never fully actualizes it in his thought. ${ }^{1}$ In other words, the lack of perpetual self-transcendence, what Tillich calls the "power of being", implies that hope cannot be truly hopeful by an individual apart from the species. While Tillich's notion of universal gift is appreciated by the reader: the absence of the possibility for the minority hope for Parousia, or second coming, within the economy of hope falls outside of the boundaries of Biblical Christianity on all accounts.

This leads to a second criticism regarding Tillich's nondiachronal God, namely, that the divine on the whole does not radically change with regard to the Christ, or his second coming. The power or motion of being might change, or change somewhat within the totality of the whole, but the being of God is not self-negating or fundamentally changing. God changes, Tillich believes, but it is a limited change established by human categories and conceptions. This change is change that can be believed in, to steal a popular cliché, as Tillich's conception of God does not allow for the incarnation of Christ to fundamentally change Godhead itself, but rather the Christ changes how beingitself or esse-ipsum is known to us and how we may participate in the ground of being.

The fundamental moment of divine change for Tillich, the Christ or the "Christ-event" is more of a theological anthropology than an actual metaphysics. "Christ" is just as much of a change for God as it is for humanity, but its meaning is defined and understood within human terms and conventions. Before Christ and after Christ the metaphysics of the divine more or less remain the same. God, of the "Power of Being" has the capacity to change humans and human situations, but this is at once understood as operating from a perspective of deus ex machina, as well as from the standpoint of human action. An interventionist deity, Peter Rollins observes, is a concept of God "introduced into the world on our terms in order to resolve a problem" and "simply justifies our beliefs and helps us sleep comfortably at night" (Rollins, 2011). If this deity offers peace in an arbitrary manner, this peace is an illusion or a conception that is self-serving.

Tillich's language about peace and how God operates in a relationship with humanity seems to be what Daly (1978) calls "doublespeak", wanting God to be thought of as a transformative mechanism of being in the world. But a limit is implied, with the possibility of final peace in an act of divine intervention by a transcendent being acting outside of the dimension of reality in which we live. To these ends, we may ask whether peace is something genuinely hoped for even as its reality is quite distant from the present? Or, whether peace is simply an esoteric matter relegated only to those who choose to think this far through Christian theology, an idea that tickles the utopian neo-liberal imagination, but can have no true actuality in the world if its peace does not come with an actual New Creation Now Occurring. ${ }^{1}$ Yet human empowerment to bring about peace is irrelevant if we are not truly invited or lured to become co-creators of the Now, or if the possibility of human empowerment towards peace is futile, as it historically stands up against a final act of the divine that would always seem to be not-yet.

\section{Radical Christology}

Radical theologian Thomas Altizer departs from Tillich on many points, but the above points on God are essential for understanding how to move beyond the liberal-existential Christianity of Tillich towards a genuine radical Christian theology. For Altizer, Godhead in the present may only be conceived as an apocalyptic Godhead in the Now, perpetually disclosing and negating Godself. The history of Godhead disclosed through scripture is the history of the death of God, culminating for Christian scripture in the resurrection of Christ, when Godhead is universally and kenotically released into human flesh. ${ }^{2}$ In this enfleshment Godhead has descended into Hell, as it has 
descended into Hell before, and the emptiness of the present "is open to an ultimate transfiguration". This transfiguration cannot be separated from the divine apocalyptic history of the incarnation, death, descent into Hell and resurrection of Christ (Altizer, 2003).

Altizer's Christological logic-which follows incarnation, death, descent into Hell and resurrection-follows the religious logic of the coincidentia oppositorum, or the coincidence of opposites. ${ }^{3}$ For Altizer, the apocalypse of Godhead follows a forward and downward movement into creation, and ultimately into human flesh with the incarnation of Christ. During the life of Christ, the ministry and crucifixion of God continues a forward and downward movement into history, and changing at every turn. Following the death of God upon the cross, the body of Jesus is entombed, and Jesus descends into Hell. At this very bottom point of forward and downward movement, God continues to move into the resurrection of Jesus, thereby unleashing the divine into human flesh as the resurrection glorifies the depths of humanity. The move from Hell to resurrection is purely symbolic, understood as forward and downward because of the enfleshment of the divine upon all people; in other words, Jesus' resurrection is not just Jesus', but rather it is the resurrection of everyone, by virtue of the crucifixion and suffering of humanity. The logic is not always clear and clean, and is easily manipulated, but should not be taken so literally as it is disclosing the logic of Godhead, a God whose logic is full of surprises and double meanings, as in the case of Godhead diachronically emptying itself into human flesh through Christ.

What is absent from the way in which Altizer has typically described his Christology is the ministry and Jesus' suffering prior to death, which are both occurrences during Jesus' temporal life and the burial of Christ following his death. There are clues to interpret these ideas in Altizer's thought, namely, that these are consistent with the kenotic movement of Godhead into flesh, and suggest forward and downward movement. A Biblical reading of Christ will demonstrate this logic; for example, the dove descending onto Christ at the moment of baptism might suggest an upward movement in terms of traditional Christological thinking (as in, "high" or "low" Christology), but the language of the Bible is a descent. Divine healing acts suggest a "high" Christology, but the healing act privileges the poor and indicates a social reversal at work. Christ's preaching suggests a high authority, but the oppressed are prioritized in the Beatitudes.

Altizer has claimed that the ascension of Christ does not fit with the logic of Godhead, the coincidentia oppositorum. ${ }^{4}$ Further, Altizer has even stated that the ascension is a symbol of an apprehension against true eschatological rendering of the Gospel; so we can argue that the concept of ascension in any literal sense has a purpose of obfuscating the final act of God from transcendence to enfleshment (Altizer, 1970). It should be recalled that the ascension is not a Pauline idea in the scriptures, but it is hinted in the longer ending of Mark and in the Luke-Acts Continuum. We know from Irenaeus (c. 180) in Against Heresies that some Gnostics believed the ascension of Christ to have occurred as late as 18 months following the resurrection, even though some other non-canonical texts (most famously the Apocryphon of James) make no mention at all of the ascension (Irenaeus, Against Heresies). Today the ascension is part of the Western and Eastern liturgical traditions and is doctrinally accepted by most Protestants. At the same time, the ascension is one of the least-discussed and perhaps least-believed elements of Christian doctrine within mainstream Christianity, and its scriptural resources are clearly suspicious or ambiguous, especially given Paul's silence on the matter. For Altizer, any historical or literal understanding of the ascension, as with the resurrection, is an apprehension of the forward and downward movement of Godhead, and it would seem that the ascension is an invention of the early church to reject the actual kenotic movement of Spirit into flesh at the event of the resurrection.

Other radical Christologies reject the ascension as well, even if their rejection is implicit. Zižek (2000), for example, writes in The Ticklish Subject that "what ultimately matters is only the resurrection of the dead Christ signaling that each human being can be redeemed and can enter the domain of Eternal Life, that is, participate in the Truth-Event". Žižek's (2009) most recent work, The Monstrosity of Christ, points towards Altzier as the only possible Christian theology following the death of God. For Žižek, radical theology points towards a resurrection of materiality in the resurrection of Christ; but for Altizer, such a belief hinges upon a literal certainty in the resurrection. Instead, the main event of Christology is in the death of God on the cross, Good Friday; anything beyond that is symbolic and is indicative of how an authentic life is lived, that is, the crucified life, in the shadow of Good Friday.

I take issue with Žižek's Christology in his language of the dead Christ. The post-resurrection Christ might have been a postdeath Jesus, but Jesus is also post-burial and post-Hell, if one is to adhere to the progression of traditional Christology. Following the death of Jesus on the cross, "human death" in a subjective sense no longer applies to him, as Godhead in Christ diachronally transfigures; the hypostasis has imploded. As such, Luther's Christological notion of communicatio idiomantum is no longer occurring in the post-resurrection image of Christ, as Christ initiates the New Creation with his own resurrection (Depoortere, 2008). I am careful not to describe Christ as a supreme superhero at this point-which is the image I retain of Christ from learning the ascension on flannelgraph as a child, where Jesus just levitates away-but the Post-Christ is, as Luke describes, "carried up into heaven" (Luke 24:50).

By "Post-Christ" I refer to the reality of Jesus following the resurrection, what Paul named the "first fruit" (1 Cor. 15:20) of the transitional period between the resurrection and, later, the ascension followed by Pentecost: "But each in his own order: Christ the first fruits, then at his coming those who belong to Christ. Then comes the end, when he hands the kingdom of God to the Father" (1 Cor. 15:23-24b) (Altizer, 1970). This scriptural language is important: if the resurrection is not a final pouring out of Godhead into human flesh, the Post-Christ would not need to be carried away, he would just levitate back to the Triune Father in the sky. The flesh of the Post-Christ is banal flesh; it must be carried away. ${ }^{5}$

\section{The Post-Christ and the ascension}

With the arrival of the first fruits of the Post-Christ and the New Creation with the event of resurrection, old thinking about the divine must transfigure, as the Christ-event has fundamentally changed any conception of God in such a cataclysmic fashion that a new post-temple epoch may be conceived. After all, "death" is an "impossible" concept for the Post-Christ, according to the Pentecost narrative in Acts 2:24. We should recall that in the apocalypse of 2 Baruch, after the destruction of the first temple, the angels inhabited the real, spiritual temple. Given Luke's nostalgia for the recently destroyed second temple, could it be possible that the ascension is a ritual exercise recalling the posttemple apocalypse of 2 Baruch? (Swanson, 2007). Even though the ascension is an upward movement, it is an ascension into a temporally destroyed temple, an apocalyptic ascension in a postresurrection world that is a final symbolic movement of an actual dissolution of Godhead into flesh. In other words, the former temples-whether inhabited by the priests or the angels, or by God for that matter-are no longer necessary because the body of 
Christ is now actually present. That is, actually present where two or more are gathered.

Turning to the Deutero-Pauline epistle to the Ephesians, the Post-Christ is described as having "put all things under his feet" and been "made ... the head over all things for the church, which is his body, the fullness of him who fills all in all" (Ephesians 1:22-23). Although "Paul" speaks of these in "the age to come" (1:21), the Gospel and apocalyptic narratives place this authority in the present. Returning to the authentic Pauline epistles, again we find that Christ is "all in all" (1 Cor. 15:28): a total presence, remaining fully divine as entangled enfleshment (Altizer, 1970).

A radical Christology must recognize that, as mentioned earlier, the ministry of Jesus formally begins with the tearing open of sky at his baptism, with Spirit descending "upon him in bodily form like a dove" (Luke 3:22). ${ }^{6}$ The Christ narrative concludes (as the Luke chapter of the Luke-Acts continuum ends) with the tearing open of sky again with the post-resurrection Post-Christ being carried away. The popular Jewish metaphysics of the time that understood the sky as an impenetrable limit should not be ignored in these images (Swanson, 2007, p. 44). In both of these moments the breeching of Absolute Hymen-to employ DG Leahy's terminology - in the act of creation is recalled, but metaphysics itself is challenged as a consequence of the death of God. As such the ascension is simultaneously a descent into Hell, transfiguring any remnant of the Pre-Christ notion of static, nondiachronal Godhead (Leahy, 1996). The ascension of the Post-Christ christens the new Christs; the ascension prepares the newly enfleshed for Christic anointing.

\section{Pentecost and the passing of the peace}

To follow this theology, the Day of Pentecost is again the tearing open of sky, the kenotic filling of Spirit, speaking with "tongues of fire" (Acts 2:1ff.). On Pentecost the hymenic sky is not closed, but open-only for downward movement of Spirit. The Church of the New Creation Now Occurring, which begins at the Day of Pentecost, tastes the abysmal openness and vacuousity of transcendence with tongues of fire as the Holy Spirit descends upon the Church. This continual downward movement, Luke tells us, is a "violent" act (Acts 2:2).

If the Church of the New Creation Now Occurring, a Pentecosting Church, is filled with tongues of fire, can there truly be peace? First, Luke makes clear that the Pentecost is universal to the hexity, or multiplicity, of the Church, but not necessarily universal to humanity as the universal gift of which Tillich spoke. Second, the divinity of this Church of the New Creation is enfleshed and is not metaphysically transcendent. As a community, this Church may anthropologically understand itself as self-transcending in the Tillichian sense, but transcendence remains a trace of the forward and downward movement, culminating in the resurrection of the Christ and the ascension of the Post-Christ. The Church diachronically occurs after the PostChrist; the Church exists contingently upon the presence of the Holy Spirit, a wind or breath speaking out of the nothing of false pentecosts happening around us.

Third, a radical Pentecosting church thrives on hope, that is, hope for an actual parousia, and hope against all odds. This hope is neither, as Tillich implies, an esoteric hope nor a hope for which its belief is strengthened by its un-believability. Rather, it is an extraordinary hope that is impossible apart from the reality of a final and ultimate joy. This eucatastrophic hope is one that grafts the individual into the apocalyptic history of Godhead, as an apocalyptic individual in Paul's epistolary historiography of Galatians, but also an ecclesiastical hope modelled upon the hope for Pentecost following the ascension. This is to say, such extraordinary hope is a hope for perpetual Pentecosting.
Is peace then possible in a radical Christian theology? Peace, in the intransitive sense, as silence, is possible, but this is only as the negation of Pentecosting tongues of fire. The practice of peace within radical liturgical environments is, however, essential for the Church of the New Creation as a dialectical action to fuel and contrast with the speaking of fire. The danger of peace is the complicity of being devoid of fire-that is, the current state of the church as a whole-yet peace is necessary for the practice of radical Christianity, to reflect upon the stillness, solitude and solipsism of radical faith in public. Silence, when deafening, is a powerful noise. The peace practiced by radical Christians, then, is not an absence of fire but is often the piercing of the Babel of nothingness in the world. Peace passes over and awaits the apocalyptic community while assembled for the festive board of the Paschal Lamb, who takes away the sin of the world (John 1:29).

Radical Christian peace is an apocalyptic peace practiced in the present as a conduit for radical Christian community. Peace is the kindling of hope, as peace is granted by the enfleshed to the enfleshed through liturgical action that eroticizes the banal; peace is a restoration and healing practice that fills our tongues with fire once again, again and again. Peace may be experienced in solitude, but is resurrected in and through community (that is, through extraordinary ecclesia). Peace may be conceived, as Tillich did, as a possibility for a final, post-Pentecostal epoch, but radical Christian peace is not exclusive to the future, and is not a state but a practice that generates hope. As mystery praxis (Nevin, 1849), peace is Pentecost Craft. Pentecosting is not an everlasting task but one that culminates into the parousia, marching on to something again New, as in Habakkuk 3, where finally, after the Christ again appears, his grace "be with all the saints" (Rev. 22:21).

\section{Notes}

1 I employ DG Leahy's terminology here, which is discussed by Altizer in The Apocalyptic Trinity (New York: Palgrave Macmillan, 163ff).

2 Altizer is the author of many books, which I assume my reader has encountered or knows by reputation. Perhaps the most succinct summaries of Altizer's theology are The Descent into Hell (Philadelphia: Lippinott, 1970) and Living the Death of God (Albany, NY: SUNY Press, 2006).

3 For more on the coincidentia oppositorum, see Altizer's Mircea Eliade and the Dialectic of the Sacred (Philadelphia: Westminster, 1963, 17ff).

4 Altizer, in an interview in the early 1970s documentary "Local Issue: God is Dead" (WGTV/University of Georgia), available online at http://video.google.com/videoplay? docid $=-3696525433308712680 \&$ ei $=$ XpihSsuiHKOmrAKGjYjvBA\&q $=$ death + of + god+video\&hl $=$ en\&client $=$ ms-rim\# .

5 I wish here to draw attention to two pieces of artwork that depict this image of the ascension: British artist Simon Bisley's illustration of the ascension provocatively offers an image of the Post-Christ as lifeless, or nearly lifeless while being carried away by an angel, but curiously, an anonymous person, whose identity is hidden from view, leads the way with a torch of light. Indonesian artist Bagong Kussudiardja's painting of the ascension features an anonymous figure-is it Jesus or humanity?-eroticized by the bird of the Spirit. These pieces may be located in Simon Bisley (Bisley, 2004) and Bagong Kussudiardja (Kussudiardja, 1995).

6 It should also be mentioned, following the earlier discussion of forward-anddownward movement, that the symbol of the bird here is connected to the resurrected "Post-Christ" as the Pauline "first fruit", namely, that birds played a role in adorning the sacrifice of the ancient Hebrew "first fruits", as presented to the Temple. This ritual is described in Deuteronomy 26, but the role of birds is depicted in the Talmud, Bikkurim 3.

\section{References}

Altizer T (1970) The Descent into Hell. Lippincott: Philadelphia, pp 106-107, $109-111$.

Altizer T (2003) The New Gospel of Christian Atheism. Davies: Aurora, CO, p 152. Bisley S (2004) Illustrations from The Bible. Heavy Metal: New York.

Daly M (1978) Gyn/Ecology. Beacon: Boston, MA, p 88.

Depoortere F (2008) The Death of God. T\&T Clark: London, pp 160-162.

Irenaeus (c. 180) Against Heresies, Book 1:30.14.

Kussudiardja B (1995) The ascension. In: Blain S (ed). Imaging the Word; Vol. 2 United Church: Cleveland, OH, p 202. 
Leahy DG (1996) Foundation. SUNY Press: Albany, NY, p 543.

Nevin JW (1849) Sartorius on the person and work of Christ. Mercersburg Review; 1 (2): 154-155.

Rollins P (2011) Insurrection. Howard: New York, pp 13-14.

Swanson R (2007) Provoking the Gospel of Luke. Pilgrim: Cleveland, $\mathrm{OH}$, pp $145-146$.

Tillich P (1990) In: Stone R (ed). Theology of Peace. Westminster/John Knox: Louisville, KY, p 189.

Žižek S (2000) The Ticklish Subject. Verso: London, p 147.

Žižek S and Milbank J (2009) In: Davis C (ed) The Monstrosity of Christ. MIT Press: Cambridge, MA, p $260 \mathrm{ff}$.

\section{Data Availability}

Data sharing not applicable to this article as no datasets were generated or analysed during the current study.

\section{Additional Information}

Competing interests: The author declares no competing financial interests.

Reprints and permission information is available at http://www.palgrave-journals.com/ pal/authors/rights_and_permissions.html

How to cite this article: Rodkey C (2015) The passing of the peace: the ascension and the death of God. Palgrave Communications. 1:15043 doi: 10.1057/palcomms.2015.43.

(c) (i) This work is licensed under a Creative Commons Attribution 3.0 International License. The images or other third party material in this article are included in the article's Creative Commons license, unless indicated otherwise in the credit line; if the material is not included under the Creative Commons license, users will need to obtain permission from the license holder to reproduce the material. To view a copy of this license, visit http://creativecommons.org/licenses/by/3.0/ 